\title{
Vascularization of the Alouatta belzebul brain base ${ }^{1}$
}

\author{
Dayane Kelly Sabec-Pereira ${ }^{2 *}$ (iD, Fabiano C. Lima ${ }^{3}$, Fabiano R. Melo ${ }^{4}$, \\ Fabiana Cristina S.A. Melo ${ }^{4}$, Kleber Fernando Pereira ${ }^{5}$ and Valcinir Aloisio S. Vulcani ${ }^{2.3}$
}

\begin{abstract}
Sabec-Pereira D.K., Lima F.C., Melo F.R., Melo F.C.S.A., Pereira K.F. \& Vulcani V.A.S. 2020. Vascularization of the Alouatta belzebul brain base. Pesquisa Veterinária Brasileira 40(4):315-323. Escola de Veterinária e Zootecnia, Universidade Federal de Goiás, Avenida Esperança s/n, Campus Samambaia, Goiânia, G0 74690-900, Brazil. E-mail: daya_ks@hotmail.com

We studied the arterial circle in the brain of five specimens of the Alouatta belzebul primate. The material had the arterial system perfused (water at $40^{\circ} \mathrm{C}$ ), injected with stained latex (Neoprene 650), fixed in aqueous formaldehyde solution (10\%) and dissected for vessel verification. The arterial circle of this primate is composed of two vascular systems: the vertebra-basilar and the carotid ones, which anastomose to close the arterial circuit. In the caudal portion of the arterial circle, there are the vertebral arteries and their branches: the rostral spinal artery and the caudal inferior cerebellar artery. The anastomosis of the vertebral arteries gives rise to the basilar artery. It presented an anatomical variation at the beginning of its path, forming a double basilar artery, called arterial island. In its course, it emitted branches giving rise to the rostral inferior cerebellar artery, the pontine arteries, the rostral cerebellar arteries, the satellite rostral cerebellar arteries and its terminal branch, the caudal cerebral artery, which presented itself in two segments: the pre-communicating one and post-communicating, joining the internal carotid artery and originating the caudal communicating artery. This group of arteries and anastomoses enclose the caudal portion of the arterial circle. From the right and left internal carotid arteries begins the rostral portion of the arterial circle, which consists of the right and left rostral cerebral arteries and the right and left middle cerebral arteries. The rostral cerebral arteries anastomose into a single trunk, giving rise to the interhemispheric artery, and in A. belzebul and Sapajus libidinosus, the rostral communicating artery is absent. The interhemispheric artery goes to the midbrain region and the corpus callosum knee divides into pericalous artery and callosarginal artery, which will supply the pre and post-central regions of the cerebral hemispheres of this species, as well as other non-human and human primates. It is noted that in the first part of the left rostral cerebral artery, there is a direct inosculation between the recurrent branch of the rostral cerebral artery and left middle cerebral artery to supply the entorhinal region. This fact also occurs in Pongo spp. The middle cerebral artery travels along the lateral sulcus where it emits several superficial branches to irrigate the superior and inferior lateral cortical regions of the frontal, parietal and temporal lobes. It is not part of the arterial circle but is the terminal branch of the internal carotid artery. A. belzebul can be considered to depend on two sources of supply to the brain: the vertebra-basilar and carotid systems, contributing to the intervention of veterinarians during clinical and surgical procedures in other primates, as well as the preservation of wild animals.
\end{abstract}

INDEX TERMS: Vascularization, Alouatta belzebul, brain base, arterial circle, neotropical primate, carotid system.

\footnotetext{
${ }^{1}$ Received on November 19, 2019.

Accepted for publication on December 16, 2019.

${ }^{2}$ Escola de Veterinária e Zootecnia, Universidade Federal de Goiás (UFG), Avenida Esperança s/n, Campus Samambaia, Goiânia, G0 74690-900, Brazil. E-mail: aloisiosv@hotmail.com; *Corresponding author: daya_ks@hotmail.com

${ }^{3}$ Universidade Federal de Jataí (UFJ), Campus Jatoba, Campus Jatobá, BR364 Km 195, Setor Parque Industrial 3800, Cidade Universitária José Cruciano
}

de Araújo, Jataí, G0 75801-615, Brazil. E-mails:fabianocl21@hotmail.com, aloisiosv@hotmail.com

${ }^{4}$ Universidade Federal de Viçosa (UFV), Av. Peter Henry Rolfs s/n, Campus Universitário, Viçosa, MG 36570-900, Brazil. E-mails: frmelo@ufv.br, fabiana.melo@ufv.br

${ }^{5}$ Universidade Federal do Paraná (UFPR), Campus Toledo, Rodovia PR182 Km 320/321, Cx. Postal 2028, Toledo, PR 85919-899, Brazil. E-mail: kleber.ufpr@gmail.com 
RESUMO- [Vascularização da base do encéfalo de Alouatta belzebul.] Estudamos o círculo arterial no encéfalo de cinco espécimes do primata Alouatta belzebul. O material teve o sistema arterial perfundido (água a $40^{\circ} \mathrm{C}$ ), injetado com látex corado (Neoprene 650), fixado em solução aquosa de formaldeído (10\%) e dissecado para verificação dos vasos. 0 círculo arterial deste primata é composto por dois sistemas vasculares: vértebro-basilar e o sistema carotídeo, que se anastomosam para fechar o circuito arterial. Na porção caudal do círculo arterial encontra-se as artérias vertebrais e seus ramos: artéria espinal rostral e a cerebelar inferior caudal. A anastomose das artérias vertebrais dá origem a artéria basilar. Esta apresentou uma variação anatômica no início do seu trajeto, formando uma dupla artéria basilar, denominada ilha arterial. Em seu trajeto emitiu ramos dando origem a artéria cerebelar inferior rostral, as artérias pontinas, as artérias cerebelares rostrais, as artérias cerebelares rostrais satélites e o seu ramo terminal, a artéria cerebral caudal, que apresentou-se em dois segmentos: o pré-comunicante e pós-comunicante, unindo-se a artéria carótida interna e originando a artéria comunicante caudal. Este grupo de artérias e anastomoses encerram a porção caudal do círculo arterial. Das artérias carótidas internas direita e esquerda, inicia-se a porção rostral do círculo arterial, ao qual é constituído pelas artérias cerebrais rostrais direita e esquerda e as artérias cerebrais médias direita e esquerda. As artérias cerebrais rostrais se anastomosam em um tronco único dando origem a artéria inter-hemisférica e em A. belzebul e Sapajus libidinosus, a artéria comunicante rostral se encontra ausente. A artéria inter-hemisférica segue para região média do encéfalo e no joelho do corpo caloso se divide em artéria pericalosa e artéria calosomarginal, que vão suprir as regiões pré e pós-central dos hemisférios cerebrais desta espécie, assim como outros primatas não humanos e humano. Nota-se que na primeira parte da artéria cerebral rostral esquerda, ocorre uma inosculação direta entre o ramo recorrente da artéria cerebral rostral e artéria cerebral média esquerda para suprir a região entorrinal, esse fato também ocorre em Pongo spp. A artéria cerebral média segue seu trajeto pelo sulco lateral onde emite vários ramos superficiais para irrigar as regiões corticais supero e ínfero lateral do lobo frontal, parietal e temporal, esta não faz parte do círculo arterial mas é o ramo terminal da artéria carótida interna. Pode-se considerar que $A$. belzebul depende de duas fontes de suprimento para o encéfalo: os sistemas vértebro-basilar e carotídeo, contribuindo na intervenção de médicos veterinários durante os procedimentos clínicos e cirúrgicos em outros primatas, assim como na preservação de animais silvestres.

TERMOS DE INDEXAÇÃO: Vascularização, base do encéfalo, Alouatta belzebul, encéfalo, círculo arterial, primata neotropical, sistema carotídeo.

\section{INTRODUCTION}

Alouatta belzebul (Linnaeus, 1766) is popularly known as bugio or guariba and, for being part of a group of neotropical primates, it presents exclusive characteristics, such as limbs and body adapted to suspending behavior and a truly prehensile long tail (Gregorin 2006). Despite the extensive amount of information available about primates, there are still gaps in knowledge about endemic or rare animals, especially anatomical studies. (Nunes \& Catão-Dias 2006). The anatomical approach of nonhuman primates is given to Old World species, such as Papio spp., popularly known as baboon and Macaca mulatta, known as monkey rhesus (Ribeiro 2006). Studies in animals of the New World began in the last century (Tilney 1928) which becomes restricted to the scientific community and the clinical and surgical routine of veterinary medicine.

Anatomical studies in different species provide information that add up and become an important source of consultation for society and the scientific community. This way, it is understood that the knowledge of the various aspects of neuroanatomy of nonhuman primates, scarce in the literature, are important not only for their intrinsic value, but also for providing a better understanding of the evolutionary process of these animals, which represents a relevant factor for its preservation and protection (Aversi-Ferreira et al. 2005).

The arterial circuit of the base of the brain has been described by other authors aiming at detailing the brain vascularization in comparative character between human, non-human primates and other vertebrates (Ferreira \& Prada 2009, Prada 2014). The arterial circle is a very important vascular pathway of the brain. Anatomocomparative studies of vessels responsible for cerebral blood flow and their anatomical variations that occur in different species of fauna may facilitate the understanding of the mechanisms responsible for the proper functioning or dysfunction of this organ (Kapoor et al. 2003, Kuchinka et al. 2008). Studies that allow for the determination of the organization, distribution, and potential differences in blood vessels at the base of the brain may also contribute to phylogenesis and ontogenesis of the brain artery (Bugge 1974). The aim of this paper is to describe the vascularization of the brain base of the Neotropical primate $A$. belzebul, focusing on the anatomical aspects of the arterial circle of this species.

\section{MATERIALS AND METHODS}

For this study, we used five Alouatta belzebul brains, collected during the rescue of terrestrial fauna during vegetation suppression activities for the implementation of Belo Monte hydroelectric exploitation, Brasília/DF, conducted by IBAMA process number 02001.001848/2006-75 and authorization number 473/2014 - 2nd rectification. After rescue, the animals were frozen and sent to the Human and Comparative Anatomy Laboratory of the "Universidade Federal de Goiás" (UFG), being kept frozen until the beginning of the experiment. The procedure involved macroscopy and dissection techniques, where the Neoprene 650 latex was injected, stained with red pigment, using as access to the thoracic aorta. Then, the pieces were fixed in $10 \%$ aqueous formaldehyde solution by intramuscular, subcutaneous and intracavitary injections. The animals were kept in this solution for at least $72 \mathrm{~h}$ and, after this period, the brains were removed from the skull with the aid of an oscillating saw (Dremel ${ }^{\circledR} 3000$ ). After removal of the brains, they returned to the $10 \%$ formaldehyde solution for a further $72 \mathrm{~h}$, so that the descriptive analyzes were then performed and photographed. All nomenclature adopted was based on Veterinary Anatomical Nomina (International Committee on Veterinary Gross Anatomical Nomenclature, ICVGAN 2017). The experimental procedure was approved by the Animal Use Ethics Committee of the UFG (protocol number 083/17). 


\section{RESULTS}

The analysis of the results of this study made it possible to observe the origin, the course and the collateral branches, as well as the terminations of the arteries that participate, in or part of it, in the formation of the arterial circle of the base of the brain of Alouatta belzebul. We have identified a division of these arteries into three vascular pedicles: the basilar artery, the right internal carotid artery and the left internal carotid artery, which have morphological features reminiscent of a hexagonal figure, arranged ventrally in relation to the brain base and rostrally to the optic chiasm (Fig.1). In the ventral region of the brain is a carotid system and in the caudal region the vertebra-basilar system.

The vertebra-basilar system forms the caudal part of the arterial circle of the brain of $A$. belzebul. The subclavian arteries originate the right and left vertebral arteries, which in the rostral region emits the rostral spinal artery, which supplies the anterior and lateral spinal cord and funiculi, and in the lateral region emits the caudal inferior cerebellar artery, the largest branch of the vertebral artery to supply the inferior and caudal region of the cerebellum (Fig.2A). Then they anastomose, originating the basilar artery.

In the basilar artery, in $100 \%$ of the specimens, we observed anatomical variation in its path, forming a double basilar

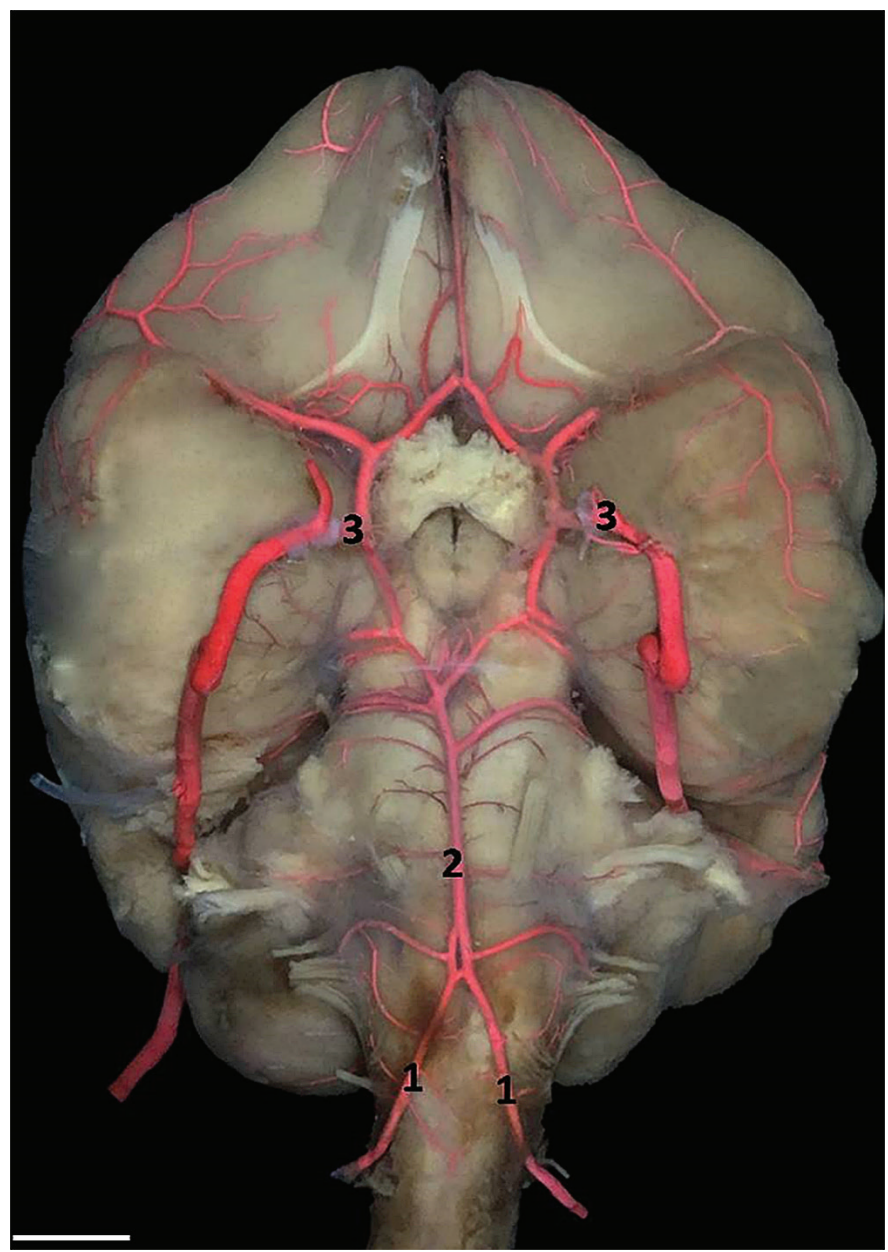

Fig.1. Arterial circle formation by right and left vertebral arteries (1), basilar artery (2) and left and right internal carotid arteries (3). Bar $=1 \mathrm{~cm}$. artery in the transition region between the bridge and the brainstem bulb, called the arterial island. This double vessel is approximately $2 \mathrm{~mm}$ and has a single segment over the bridge extension (Fig.2B).

The first large branch of the basilar artery is the right and left rostral inferior cerebellar artery, which supplies the rostral inferior portion of the cerebellum. The pontine arteries in the mid-lateral region of the basilar artery supply the bridge and the right and left rostral cerebellar arteries and satellite rostral cerebellar arteries, terminal branches of the basilar artery, supply the cranial part of the cerebellum (Fig.3).

The caudal cerebral artery is divided into two segments: the pre-communicating artery, this part of the artery between the basilar artery bifurcation and the caudal communicating artery, and the post-communicating artery between the caudal communicating artery and the temporal branches, which supply the medial and lateral regions of the midbrain and the occipital pole and inferior margin of the temporal lobe. The caudal communicating artery, formed by the union of the internal carotid artery and the caudal cerebral artery, runs laterally to supply the pituitary and the nipple bodies.

The other vascular system we identified in $A$. belzebul is the carotid system, consisting of the right and left internal carotid arteries, which emits two main branches: the rostral cerebral artery that ends the arterial circle to the base of the brain and the middle cerebral artery (Fig.4).

The rostral cerebral artery runs through the anterior encephalic region at the base of the cerebral peduncle, infundibular and chiasmatic region. Moreover, near the longitudinal cleft of the brain is an anastomosis between the rostral cerebral artery with its contralateral homonymous, forming a single trunk giving rise to the interhemispheric artery (Fig.4). This artery was observed in $100 \%$ of the specimens analyzed and with symmetrical vascular gauges, sending branches to supply

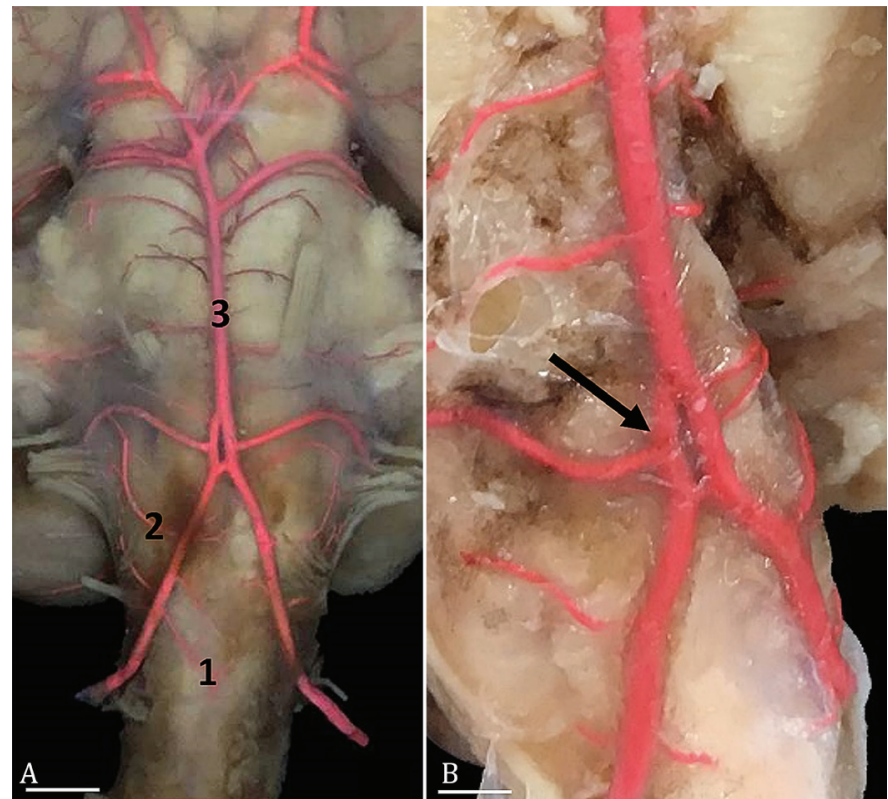

Fig. 2. (A) Brainstem of Alouatta belzebul highlighting the rostral spinal artery (1), caudal inferior cerebellar artery (2) and basilar artery (3). Bar $=0.8 \mathrm{~cm}$. (B) Double basilar artery (arrow) of $A$. belzebul forming an arterial island at the beginning of vertebral artery anastomosis. Bar $=0.4 \mathrm{~cm}$. 
cortical areas of the anterior perforated substance, orbital region, straight gyrus, medial surface of the sub-rostral sulcus, frontal pole, anterior frontal, middle and posterior regions, corpus callosum and grooves, pre-central region, upper part of pre- and post-central gyrus and pre-cuneal region (Fig.5).

The union of the rostral cerebral arteries gives rise to the interhemispheric artery and it forks in the knee region of the corpus callosum into two terminal branches called the

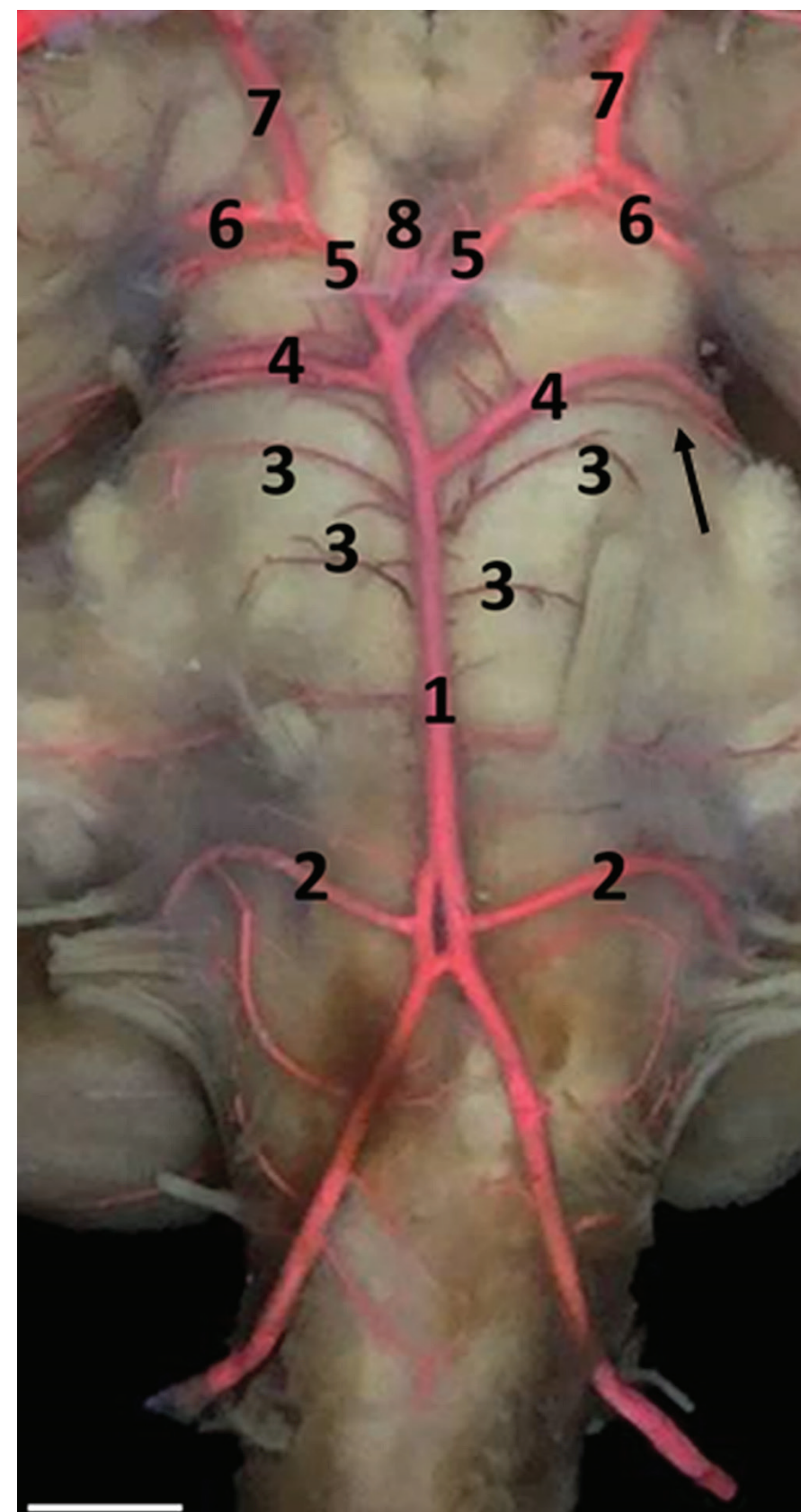

Fig.3. Basilar artery (1) and its branches in the vertebra-basilar system of Alouatta belzebul. Right and left rostral inferior cerebellar artery (2), right and left pontine arteries (3), right and left rostral cerebellar artery (4), satellite rostral cerebellar artery (arrow), pre-communicating caudal cerebral artery (5), cerebral artery post-communicating caudal flow (6), caudal communicating artery (7) and branches for the chiasmatic region $(8)$. Bar $=0.8 \mathrm{~cm}$. pericalous artery and the calosmarginal artery (Fig.5). These two terminal branches continue the path by branching into the brain gyrus from the main trunk at acute angles, directed to the medial surface of $A$. belzebul's cerebral hemisphere. The branches of the calosomarginal artery go to the regions of the cortex in the upper and pre-central frontal branches, and the branches of the pericalous artery go to the post-central and precununal regions (Fig.5). In the first part of the left rostral cerebral artery, there is a direct inosculation between the recurrent branch of the rostral cerebral artery and the left middle cerebral artery to supply the entorhinal region (Fig.6).

The even-sized middle cerebral artery branches from the internal carotid artery and laterally traverses the lateral sulcus between the inferior frontal gyrus and the superior temporal gyrus without forming part of the contour formation of the arterial circle. Along the way, it emits branches that vascularize most of the inferolateral face of each cerebral hemisphere,

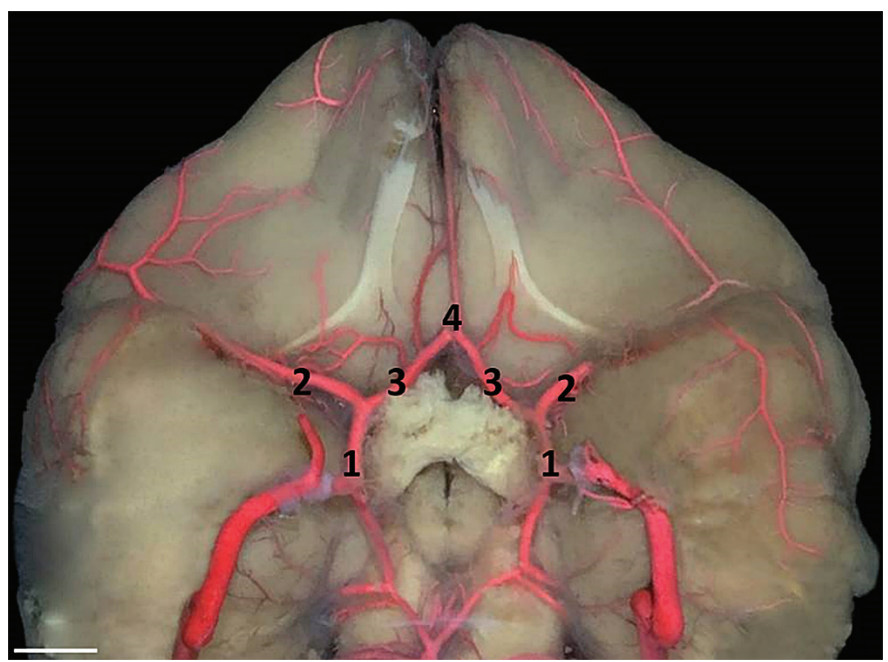

Fig.4. Alouatta belzebul carotid system formed by the right and left internal carotid arteries (1), right and left middle cerebral artery (2), right and left rostral cerebral artery (3) and interhemispheric artery (4). Bar $=0.6 \mathrm{~cm}$.

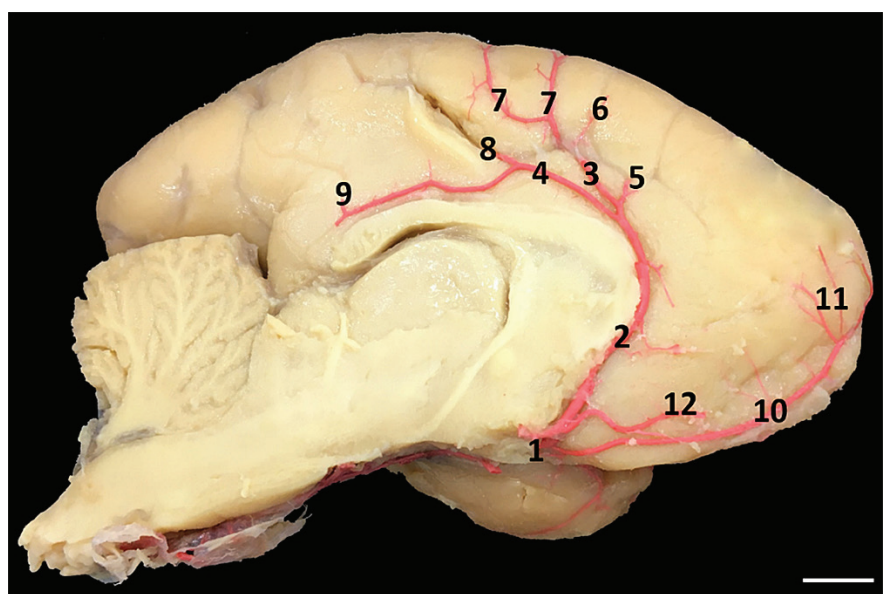

Fig.5. Left rostral cerebral artery (1), interhemispheric artery (2), callosalginal artery (3), pericalous artery (4), rostral frontal artery (5), middle frontal artery (6), caudal frontal artery (7), post-central artery (8), pre-cuneal artery (9), frontal polar artery (10), frontal polar artery branches (11) and anteromedial frontal branch of the interhemispheric artery (12). Bar $=1.2 \mathrm{~cm}$. 
namely: the lateral basilar frontal artery, pre-central sulcus artery, central sulcus artery, postcentral sulcus artery, parietal artery rostral, temporo-occipital branch, caudal temporal branch, middle temporal branch and rostral temporal branch (Fig.7). The main vessels that form the arterial circle of Old and New World primates are shown in Table 1.

\section{DISCUSSION}

In this study, it was observed that in Alouatta belzebul, the vertebra - basilar system occurs through an irrigation anastomosis between the right and left vertebral arteries, the basilar artery and the right and left caudal cerebral arteries, corroborating the findings in Pongo spp. (Shellshear 1927), Pan spp. and family Hylobatidae (Watts 1934b), Macaca mulatta (Kassel \& Langefitt 1965), Homo spp. (Gardner et al.

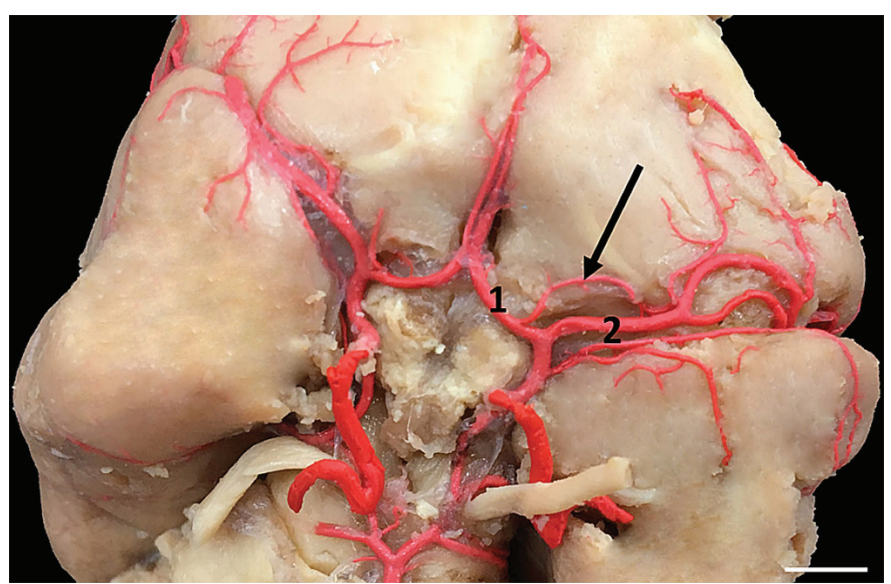

Fig.6. Inoculation (arrow) of the rostral cerebral artery (1) with the middle cerebral artery (2) in the anterior part. Bar $=0.6 \mathrm{~cm}$.
1978) and Sapajus libidinosus (Ferreira \& Prada 2001, 2009). The caudal arterial supply comes from the vertebral arteries, to which they anastomose and form the caudal portion of the arterial circle. The intracranial vertebral artery ascends medially rostral to the spinal cord and the inferior border of the bridge, and the two vertebral arteries join to form the basilar artery.

The vertebral artery in $A$. belzebul originates at the level of the inferior border of the olivary eminence and joins with its counterpart to form the basilar artery. Branching from the vertebral arteries is the rostral spinal artery, which

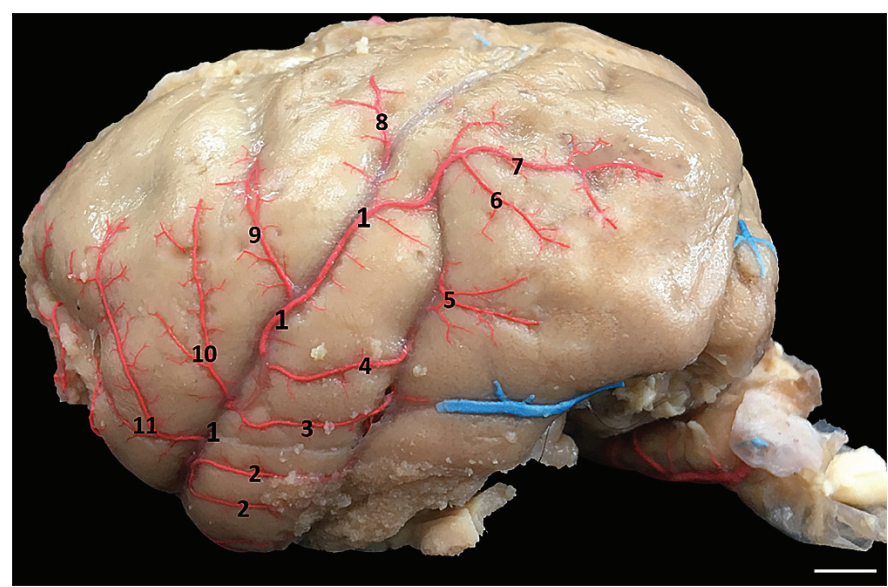

Fig.7. Middle cerebral artery (1) and its branches: rostral temporal branch (2), middle temporal branch (3), caudal temporal branch (4), temporo-occipital branch (5), inferior parietal artery (6), rostral parietal artery ( 7), post-central sulcus artery (8), central sulcus artery (9), pre-central sulcus artery (10) and lateral basilar frontal artery (11). Bar $=1.2 \mathrm{~cm}$.

Table 1. Comparative data on arterial circle formation in primates

\begin{tabular}{|c|c|c|c|c|c|c|c|c|c|c|}
\hline $\begin{array}{l}\text { Taxonomic } \\
\text { group }\end{array}$ & Taxon & $\begin{array}{l}\text { Popular } \\
\text { name }\end{array}$ & $\begin{array}{l}\text { Vertebral } \\
\text { artery }\end{array}$ & $\begin{array}{l}\text { Basilar } \\
\text { artery }\end{array}$ & $\begin{array}{l}\text { Caudal } \\
\text { cerebral } \\
\text { artery }\end{array}$ & $\begin{array}{c}\text { Caudal } \\
\text { communicating } \\
\text { artery }\end{array}$ & $\begin{array}{l}\text { Internal } \\
\text { carotid } \\
\text { artery }\end{array}$ & $\begin{array}{l}\text { Rostral } \\
\text { cerebral } \\
\text { artery }\end{array}$ & $\begin{array}{c}\text { Rostral } \\
\text { communicating } \\
\text { artery }\end{array}$ & $\begin{array}{c}\text { Interhemispheric } \\
\text { artery }\end{array}$ \\
\hline New World & $\begin{array}{l}\text { Alouatta } \\
\text { belzebul }\end{array}$ & Bugio & $\mathrm{X}$ & $\begin{array}{c}\mathrm{X} \\
\text { (arterial } \\
\text { island) }\end{array}$ & $\mathrm{X}$ & $\mathrm{X}$ & $\mathrm{X}$ & $\mathrm{X}$ & Absent & $\mathrm{X}$ \\
\hline New World & $\begin{array}{c}\text { Sapajus } \\
\text { libidinosus }\end{array}$ & $\begin{array}{l}\text { Capuchin } \\
\text { monkeys }\end{array}$ & $\mathrm{X}$ & $\begin{array}{c}\mathrm{X} \\
\text { (arterial } \\
\text { island) }\end{array}$ & $\mathrm{X}$ & $\mathrm{X}$ & $\mathrm{X}$ & $\mathrm{X}$ & Absent & $\mathrm{X}$ \\
\hline Old World & Pongo spp. & Orangutan & $\mathrm{X}$ & $\mathrm{X}$ & $\mathrm{X}$ & $\mathrm{X}$ & $\mathrm{X}$ & $\mathrm{X}$ & $\mathrm{X}$ & Absent \\
\hline Old World & Pan spp. & Chimpanzee & $\mathrm{X}$ & $\mathrm{X}$ & $\mathrm{X}$ & $\mathrm{X}$ & $\mathrm{X}$ & $\mathrm{X}$ & Absent & Absent \\
\hline Old World & Hylobatidae & Gibbon & $\mathrm{X}$ & $\mathrm{X}$ & $\mathrm{X}$ & $\mathrm{X}$ & $\mathrm{X}$ & $\mathrm{X}$ & Absent & \\
\hline Old World & $\begin{array}{l}\text { Homo } \\
\text { sapiens }\end{array}$ & Human & $\mathrm{X}$ & $\mathrm{X}$ & $\mathrm{X}$ & $\mathrm{X}$ & $\mathrm{X}$ & $\mathrm{X}$ & $\mathrm{X}$ & Absent \\
\hline Old World & $\begin{array}{c}\text { Macaca } \\
\text { mulata }\end{array}$ & Rhesus & $\mathrm{X}$ & $\mathrm{X}$ & $\mathrm{X}$ & $\mathrm{X}$ & $\mathrm{X}$ & $\mathrm{X}$ & $\mathrm{X}$ & Absent \\
\hline Old World & $\begin{array}{c}\text { Papio } \\
\text { ursinus }\end{array}$ & Baboon & $\mathrm{X}$ & $\mathrm{X}$ & $\mathrm{X}$ & $\mathrm{X}$ & $\mathrm{X}$ & $\mathrm{X}$ & Absent & $\mathrm{X}$ \\
\hline Old World & $\begin{array}{c}\text { Cercopithecus } \\
\text { pygerithrus }\end{array}$ & Vervet & $\mathrm{X}$ & $\mathrm{X}$ & $\mathrm{X}$ & $\mathrm{X}$ & $\mathrm{X}$ & $\mathrm{X}$ & Absent & $\mathrm{X}$ \\
\hline Old World & $\begin{array}{c}\text { Galago } \\
\text { senegalensis }\end{array}$ & Bushbaby & $\mathrm{X}$ & $\mathrm{X}$ & $\mathrm{X}$ & $\mathrm{X}$ & $\mathrm{X}$ & $\mathrm{X}$ & Absent & $\mathrm{X}$ \\
\hline
\end{tabular}

Source: Lake et al. 1990 (modified). 
presents a ventral downward pathway to the spinal cord and anastomoses with its counterpart to form a median trunk that supplies the lateral and dorsal regions of the spinal cord. This morphological arrangement is similar in Pongo spp. (Shellshear 1927) and Homo spp. (Amato \& Stolf 2015). In these species, it was also observed the presence of perforating, segmental and longitudinal rostral spinal arteries that form an irrigation channel connecting the perforating and segmental with the same function. These branches were not identified in $A$. belzebul.

The caudal and rostral inferior cerebellar arteries were observed in $100 \%$ of the analyzed specimens. The caudal inferior cerebellar artery is a branch of the vertebral artery and irrigates the posteroinferior surface of the cerebellum. Its caliber is smaller than the rostral inferior artery, unlike that observed in S. libidinosus (Silva \& Ferreira 2002b), which presented a larger caliber in the caudal inferior cerebellar artery. The rostral inferior cerebellar artery is a branch of the basilar artery, its path runs posteriorly around the olives, between the roots of the hypoglossal nerve, and caudally to the roots of the vagus and glossopharyngeal nerves, vascularizing the inferior surface of the cerebellum, the inferior worm, the tonsil and the inferolateral surface of the cerebellar hemisphere. In Papio ursinus, Cercopithecus pygerithrus and Galago senegalensis, the caudal and rostral inferior cerebellar arteries originate from a single trunk called the common inferior cerebellar artery (Lake et al. 1990). This common vessel is absent in $A$. belzebul, as well as in S. libidinosus (Silva et al. 2003, Silva \& Ferreira 2003) and Homo spp. (Meneses 2015). Elze (1910) described that in Ateles paniscus one or two caudal inferior cerebellar arteries and one or two rostral inferior cerebellar arteries (or internal auditory artery) are present, which was not observed in $A$. belzebul, where only a single right and left branch was identified from each artery.

By joining the right and left vertebral arteries there is the formation of the basilar artery. In A. belzebul, the path begins at the lower edge of the bridge passing through the longitudinal groove, differing from the findings of Shellshear (1927), who reports that in Pongo spp. the origin is at the lower edge level of the olive eminence. In all species found in the literature and in A. belzebul, this artery terminates at the upper edge of the bridge, emitting four branches: the pontine arteries, which supply the brainstem bridge; the inferior and superior cerebellar even arteries, which supply the bridge and cerebellum; and the caudal cerebral arteries, which are the terminal branches of the basilar artery, supplying most of the temporal and occipital lobes and joining with the caudal communicating arteries to form the vertebra-basilar system of the arterial circle. This pattern has also been described in other nonhuman primates such as Pongo spp. (Shellshear 1927), Pan spp. and Hylobatidae (Watts 1934b), M. mulatta (Kassel \& Langefitt 1965), S. libidinosus (Ferreira \& Prada 2001, Prada 2014) and human (Gardner et al. al. 1978).

In the initial course of the basilar artery, in $A$. belzebul was observed the formation of a double basilar artery, which is called arterial island. This data was also described in $S$. libidinosus (Ferreira \& Prada 2001), which describes the arterial island as a variation in the fusion of this blood vessel.

The rostral cerebellar artery of $A$. belzebul is a collateral branch dependent on the large basilar artery. Reaches the upper part of the cerebellum, its branches go to the upper worm and to the remaining hemispherical portions of the upper and lateral region. Its origin, path and distribution corroborate the findings for P. ursinus, C. pygerithrus and $G$. senegalensis (Lake et al. 1990), S. libidinosus (Silva \& Ferreira 2002 b) and Homo spp. (Gardner et al. 1978).

The rostral cerebellar arteries of $A$. belzebul are often accompanied at their origins by a smaller caliber satellite vessel, the rostral satellite cerebellar artery, also observed in S. libidinosus (Ferreira 1997, Silva \& Ferreira 2002a, Silva \& Ferreira 2003), and absent in other primates. This satellite vessel is mainly arboreal in the bridge region and anastomoses with the lateral branch of the rostral cerebellar artery in the lateral vicinity of the superior semilunar lobe. It is noteworthy that, according to the De Vriese's classification (De Vriese 1905), primates present a well-elaborated vascularization model, where the cerebellum vessels are dependent on the vertebra-basilar system, with few variations. This has been confirmed for $A$. belzebul, which we understand to be indicative of a relative morphological and functional stability, which allows us to consider that this richness of interconnections may mean an important aspect of the adaptation of the cerebellum to the tree locomotion of this species, whose rapid dislocations on the ground and at the height of the forests where they are found require extremely flexible and adapted cerebellar blood flow.

The caudal cerebral artery in $A$. belzebul was observed in $100 \%$ of the specimens. This artery is divided into two segments: the pre-communicating artery, located between the basilar artery bifurcation and the caudal communicating artery, and the postcommunicating artery, between the caudal communicating artery and the temporal branches, which supply cortical collateral branches, the medial and lateral regions of the midbrain, parietal, occipital pole and inferior border of the temporal lobe.

In all analyzed brain, the origin of the caudal cerebral artery was forked from the basilar artery as a terminal branch, corroborating with other authors who described this artery in P. ursinus, C. pygerithrus and G. senegalensis (Lake et al. 1990), S. libidinosus (Siqueira \& Ferreira 2002), Pan spp. (Sperino 1897, Shellshear 1930); M. mulatta (Weinstein \& Hedges 1962, Kassel \& Langefitt 1965); Pongo spp. (Shellshear 1927); in Hylobatidae (Watts 1934b); and Homo spp. (Testut \& Latarjet 1954, Gillilan 1969, Machado \& Haertel 2014).

The caudal communicating artery in $A$. belzebul presents itself as a branch of the union of the internal carotid artery with the caudal cerebral artery, and its course runs laterally to the cerebral hemisphere to supply the pituitary and nipple bodies. In S. libidinosus (Ferreira \& Prada 2009), the caudal communicating artery has the same configuration, which delimits the caudal part of the arterial circle with the vertebra-basilar system.

The other system described for A. belzebul's arterial circle was the carotid artery. This occurs through an irrigation anastomosis between the right and left internal carotid arteries that emit two main branches: the right and left rostral cerebral arteries, which terminate the arterial circle in the rostral portion, and the middle cerebral artery to the medial region of the brain.

The internal carotid artery of $A$. belzebul, in the intracranial segment, follows its path laterally to the optic nerve and medially to the oculomotor nerve. This vessel gives rise to its two terminal branches: the rostral cerebral artery and 
the middle cerebral artery, according to findings in Pan spp. (Shellshear 1930), Cereophitecidae and Cebidae (Watts 1934b); M. mulatta (Dyrud 1944, Lineback 1961, Weinstein \& Hedges 1962), Gorilla spp. (Raven \& Hill 1950), Homo spp. (Testut \& Latarjet 1954), S. libidinosus (Ferreira \& Pires 2004, Ferreira \& Prada 2009), Pongo spp. (Watts 1934b) and P. ursinus, C. pygerithrus and G. senegalensis (Lake et al. 1990).

The rostral cerebral artery in $A$. belzebul is a terminal branch of the right and left internal carotid arteries. Its origin is medially related to the optic chiasm, passing dorsally to the optic tract and caudally to the olfactory bulbs. After emitting the olfactory arteries, the rostral cerebral artery goes to the longitudinal fissure of the brain where it anastomoses with its contralateral homonymous forming a single trunk to which the interhemispheric artery originates. This segment follows the longitudinal fissure of the brain passing dorsally to the knee of the corpus callosum, where it emits collateral branches to the two cerebral hemispheres. In the knee region of the corpus callosum, it ends by bifurcating into the calosmarginal artery and pericalous artery, both with directions to the right and left antimers. This arterial distribution favors the cerebral cortical regions: prefrontal, frontopolar, superior frontal, pre-central and postcentral, similar to the findings in S. libidinosus (Ferreira \& Pires 2004, Ferreira et al. 2005).

In Homo spp. (Meneses 2015), Pongo spp. and Pan spp. (Watts 1934a), the rostral cerebral artery bifurcates from the internal carotid artery and runs medially and anteriorly to the longitudinal fissure of the brain, where it makes an anastomosis with its contralateral counterpart through the rostral communicating artery, and then follow separated to the cortical areas. This pattern differs in M. mulatta and $P$. cynocephalus, where the arteries join and then separate into a spiral loop to supply the cerebral hemispheres (Kassel \& Langefitt 1965, Lake et al. 1990). This communicating branch is absent in A. belzebul, as well as in S. libidinosus (Ferreira et al. 2005, Ferreira \& Prada 2009).

Another important consideration in $A$. belzebul is that a direct inosculation with the middle cerebral artery was observed in the first portion of the left rostral cerebral artery. This inoculation has also been found in Pongo spp. (Shellshear 1927) on the same brain antigen, which gives rise to the striated arteries for the endorhinal fissure. The usual anatomical condition of this inoculation is to be present on the right side, where the striated branches of the two arteries are separated from each other.

The pericalous artery and callosarginal artery represent the terminal branches of the interhemispheric artery, with a bifurcation at the level of the caudal half of $A$. belzebul's corpus callosum. In S. libidinosus (Pires \& Ferreira 2004), other arrangements for bifurcation of the interhemispheric artery were observed. However, in both species the arteries supply the polar front region, the pre-central region and the post-central region, which resembles the arterial supply model described for Pan spp., Pongo spp., M. mulatta, Hylobatidae and Ateles paniscus (Watts 1934b).

The calosmarginal artery in A. belzebul is a branch of the interhemispheric artery that bifurcated at the level of the caudal half of the corpus callosum, following the cingulate groove, where it gave rise to three frontal arteries: superior frontal artery, middle frontal artery, and posterior frontal artery. They are important for supplying pre- and post-central cerebral cortical areas, linked to motor activity. In Homo spp. (Martin 2013, Meneses 2015) and Pongo spp. (Lemos 1984), the calosomarginal artery presents anatomical and angiographic variations, which may become a direct branch of the pericalous artery. Due to this variability in arterial arrangements, Perlmutter \& Rhoton (1978) report that in microsurgery in humans, it is possible to define the calosomarginal artery only as the artery that runs through the cingulate groove and gives rise to two or more cortical branches.

The pericalous artery in A. belzebul is also a branch of the interhemispheric artery that bifurcates parallel to the callosarginal artery in the caudal part of the knee of the corpus callosum and follows the groove of the corpus callosum. This vessel branches into the post-central and pre-cuneal arteries to supply the postcentral and pre-cuneal areas, responsible for overall sensitivity and primary visual function, respectively. In these regions, the pericalous arteries overlap in the border areas of the vascularization territory, which may reinforce the importance of the pericalous arteries and their branches in the blood supply of these cerebral cortical areas in A. belzebul. This same description was found in S. libidinosus (Pires \& Ferreira 2004).

The middle cerebral artery in A. belzebul is the largest caliber branch of the internal carotid artery bifurcation, laterally following the lateral sulcus between the inferior frontal gyrus and the superior temporal gyrus without forming part of the contour formation of the arterial circle. Along the way, it emits deep branches that encompass the perforating branches and, consequently, deep brain areas such as the inner capsule, base nuclei and superficial branches. These deep and superficial branches vascularize most of the superinferior and inferior lateral face of each cerebral hemisphere through the arteries: lateral basilar frontal, pre-central sulcus artery, central sulcus artery, postcentral sulcus artery, and rostral parietal artery in the previous part, and in the inferior region of the temporal lobe the arteries: temporo-occipital branch, caudal temporal branch, middle temporal branch and rostral temporal branch.

In $S$. libidinosus, the middle cerebral artery did not participate in the formation of the arterial circuit of the base of the brain. It can be interpreted as a terminal branch of constant and symmetrical disposition and, after its origin, is insinuated in the lateral sulcus, going through it to subdivide into the corresponding hemispheres (Ferreira \& Prada 2009). The authors describe that after detaching from the carotid trunk the middle cerebral artery emits a branch collateral to the chorioid artery.

In P. ursinus, C. pygerithrus and $G$. senegalensis (Lake et al. 1990), the middle cerebral artery follows the same path as in $A$. belzebul and emits the first branches, called medial striated arteries. These ascend through the lentiform nucleus to irrigate the caudate nucleus head and the lateral striated arteries that ascend into the outer capsule, supplying the caudate nucleus capsule and body, and the branches of these arteries supply the thalamus. The middle cerebral artery in these three species also supplies the insular lobe through its branches and travels to the surface of the cerebral hemispheres where it provides convex branches for irrigation of cortical areas. In Homo spp. (Meneses 2015), the middle cerebral artery also presents itself as a large vessel of the internal carotid artery bifurcation and follows the same path observed in A. belzebul to irrigate the superficial and deep regions of the cerebral hemispheres. 


\section{CONCLUSIONS}

The brain vascularization of Alouatta belzebul depends on two irrigation systems: the vertebra-basilaris and the carotid, where an artery anastomosis occurs and form the closed circuit that supplies the brain. The vertebral arteries of $A$. belzebul give rise to the basilar artery, which forms an arterial island at its origin by demonstrating a double basilar artery and then follows its single path through the basilar sulcus to emit its terminal branch, the caudal cerebral artery.

The caudal cerebral artery is subdivided into arterial segments: pre-communicating and post-communicating and will supply the medial and lateral areas of the brain. The right and left internal carotid arteries emit their terminal branches, being the rostral cerebral artery and the middle cerebral artery, which make an anastomosis and close the rostral part of the arterial circle. The right and left rostral cerebral arteries unite to form the interhemispheric artery that follows its path through the cerebral hemispheres, giving rise to the pericalous artery and the calosomarginal artery to supply the pre and post central areas of the brain cortex. The middle cerebral artery and rostral cerebral artery anastomose by direct inoculation indicating uniform flow. In addition, in its path emits several superficial branches to supply the frontal and temporal areas of the cerebral cortex.

Alouatta belzebul presents a blood supply model considered efficient for the exercise of the function and complex, due to the various aspects discussed in this paper. The blood supply dependent on the arterial circle presents a constancy of blood flow, which suggests experimental models for the treatment of vascular disorders. The similarity of Old and New World primate species can provide experimental data in clinical trials for aneurysm treatment, for example. The constancy of the vessels and absence of abnormalities in the A. belzebul's cerebral arterial circuit also suggest a complex model and may contribute to the intervention of veterinarians during clinical and surgical procedures in other primates.

Acknowledgments.- To Carlos Eduardo Sabec for the contribution and treatment of the images presented in this study. To the "Coordenação de Aperfeiçoamento de Pessoal de Nível Superior" (CAPES) for the financial support. To the postgraduate program in Animal Science of the "Universidade Federal de Goiás" (UFG), Goiânia, for the support in the infrastructure of the research laboratories. Naturae Environmental Consulting for the grant of cadaverous material for the development of this study.

Conflict of interest statement.- The authors have no conflict of interest.

\section{REFERENCES}

Amato A.C.M. \& Stolf N.A.G. 2015. Anatomia da circulação medular. J. Vasc. Bras. 14(3):248-252.<http://dx.doi.org/10.1590/1677-5449.0004>

Aversi-Ferreira T.A., Aversi-Ferreira R.A.G.M.F., Silva Z., Gouvêa e Silva L.F. \& Penha-Silva N. 2005. Estudo anatômico de músculos profundos do antebraço de Cebus apella (Linnaeus, 1766). Acta Scient., Biol. Sci. Maringá, 27(3):297-301. <http://dx.doi.org/10.4025/actascibiolsci.v27i3.1351>

Bugge J. 1974. The cephalic arterial system in insetivores, primates, rodents and lagomorphs, with special reference to the sistematic classification. Acta Anat. 87(Suppl.62):1-160. <http://dx.doi.org/10.1159/isbn.978-38055-8706-8> <PMid:4207099>

De Vriese B. 1905. Sur la significtion morfologique des artéres cerebrales. Arch. Biol. 21:357-457.
Dyrud J. 1944. The external carotid artery of the rhesus monkey (Macaca mulatta). Anat. Rec., Philadelphia, 90(1):17-22. <http://dx.doi.org/10.1002/ ar.1090900103>

Elze C. 1910. Über das verhalten der arteria basilaris bei verschiedenen species des Genus Ateles. Anat. Anz. 37(1):33-38.

Ferreira J.R. \& Pires J.S. 2004. Estudo anatômico dos ramos da artéria cerebral rostral destinados a região olfatória do encéfalo de primatas neotropicais (Cebus apella Linnaeus, 1766). Vet. Not. 10(2):17-23.

Ferreira J.R. \& Prada I.L.S. 2001. Nomenclatura proposta para denominar as artérias da base do encéfalo do macaco-prego (Cebus apella L., 1766). Acta Scient., Biol. Sci. 23(2):635-643. <http://dx.doi.org/10.4025/ actascibiolsci.v23i0.2726>

Ferreira J.R. \& Prada I.L.S. 2009. The carotid encephalic system of the Cebus apella sp. Linnaeus, 1766. Biota Neotrop. 9(1):286-292 <http://dx.doi. org/10.1590/S1676-06032009000100032>

Ferreira J.R., Abreu N.H.L., Pires J.S. \& Ribeiro B.N. 2005. 0 sistema carótico do encéfalo de primata neotropical, anatomia da artéria Inter-hemisférica (Cebus apella Linnaeus, 1766). Ciênc. Anim. Bras. 6(3):203-212.

Ferreira J.R.1997. Estudo anatômico das artérias da base do encéfalo do macaco prego (Cebus apella Linnaeus, 1766). Doctoral Dissertation, Universidade de São Paulo, Faculdade de Medicina Veterinária e Zootecnia, São Paulo, SP. 159p.

Gardner E., Gray D.J. \& O’Rahilli R. 1978. Anatomia: estudo regional do corpo humano. $4^{\text {a }}$ ed. Guanabara Koogan, Rio de Janeiro. 828p.

Gillilan L.A.1969. The arterial and venous blood supplies to the cerebellum of primates. J. Neuropathol. Exp. Neurol. 28(2):295-307. <http://dx.doi. org/10.1097/00005072-196904000-00009>

Gregorin R. 2006. Taxonomia e variação geográfica das espécies do gênero Alouatta lacépéde (Primates, Atelidae) no Brasil. Revta Bras. Zool. 23(1):64144. <http://dx.doi.org/10.1590/S0101-81752006000100005>

ICVGAN 2017. Nomina anatomica veterinaria. International Committee on Veterinary Gross Anatomical Nomenclature (ICVGAN). 6th ed. Interamericana, Rio de Janeiro.

Kapoor K., Kak V.K. \& Singh B. 2003. Morphology and comparative anatomy of circulus arteriosus cerebri in mammals. Anat. Histol. Embryol. 32(6):347-355. <http://dx.doi.org/10.1111/j.1439-0264.2003.00492.x><PMid:14651482>

Kassel N.F. \& Langefitt T.W. 1965. Variations in the circle of Willis in Macaca mulatta. Anat. Rec. 152(3):257-263. <http://dx.doi.org/10.1002/ ar.1091520305> <PMid:4955228>

Kuchinka J., Nowak E., Szczurkowski M.A. \& Kuder T. 2008. Arteries supplying the base of the brain in the Mongolian gerbil (Meriones unguiculatus). Pol. J. Vet. Sci. 11(4):295-299. <PMid:19227126>

Lake A.R., Van Niekerk I.J.M., Le Roux C.G.J., Trevor- Jones T.R. \& De Wet P.D. 1990. Angiology of the brain of the baboon Papio ursinus, the vervet monkey Cercopithecus pygerithrus, and the bushbaby Galago senegalensis. Am. J. Anat. 187(3):277-286. <http://dx.doi.org/10.1002/aja.1001870307> $<$ PMid:2321560>

Lemos V.P.J. 1984. Frequência da artéria calosomarginal e proposição de hipótese quanto ao seu significado filogenético. Arq. Neuropsiquiatria 42(4):335-340. <http://dx.doi.org/10.1590/S0004-282X1984000400004>

Lineback P. 1961 The vascular system, p.249-255, 281. In: Hartman C.G. (Ed.), The Anatomy of the Rhesus Monkey. Hafener, New York.

Machado A. \& Haertel L.M. 2014. Neuroanatomia Funcional. $33^{\mathrm{a}}$ ed. Atheneu, Rio de Janeiro, p.84-89.

Martin J.A. 2013. Neuroanatomia: texto e atlas. 4aㅡ ed. AMGH, Porto Alegre, p.57-66.

Meneses M.S. 2015. Neuroanatomia Aplicada. 3르 ed. Guanabara Koogan, Rio de Janeiro, p.295-306. 
Nunes A.L.V. \& Catão-dias J.L. 2006. Primates: primatas no velho mundo (babuíno, mandril, chimpanzé, orangotango). In: Cubas Z.S., Silva J.C.R. \& Catão-Dias J.L. (Eds), Tratado de Animais Selvagens. Roca, São Paulo, p.378-401.

Perlmutter D. \& Rhoton Jr. A.L. 1978. Microsurgical anatomy of the distal anterior cerebral artery. J. Neurosurg. 49(2):204-228. <http://dx.doi.org/ 10.3171/jns.1978.49.2.0204>

Pires J.S. \& Ferreira J.R. 2004. Anatomia das artérias pericalosas do encéfalo de primata neotropical e seus ramos frontais e parietais (Cebus apella Linnaeus, 1766). Braz. J. Vet. Res. Anim. Sci. 41(3):207-214. <http://dx.doi. org/10.1590/S1413-95962004000300010>

Prada I. 2014. Neuroanatomia Funcional em Medicina Veterinária com Correlações Clínicas. Editora Terra Molhada, São Paulo, p.300-335.

Raven H.C. \& Hill J.H. 1950. Regional anatomy of the gorilla, part II, p.2426, 114-115. In: Raven H.C. (Ed.), The Anatomy of the Gorilla. Columbia University Press, New York.

Ribeiro A.R. 2006. Aspectos morfológicos da hipófise do macaco Cebus apella. Doctoral Dissertation, Faculdade de Medicina Veterinária e Zootecnia, Universidade de São Paulo, São Paulo, SP. 60p.

Shellshear J.L. 1927. The arteries of the brain of the Orangutan. J. Anat. 61(Pt 2):167-197. <PMid:17104131>

Shellshear J.L. 1930. The arterial supply of the cerebral cortex in the chimpanzee (Anthropopithecus troglodytes). J. Anat. 65(Pt 1):45-87. <http://dx.doi. org/10722/197984><PMid:17104307>

Silva R.A. \& Ferreira J.R. 2002a. Estudo das artérias cerebelares do macaco prego: considerações sobre a nomenclatura (Cebus apella L., 1766). Braz. J. Vet. Res. Anim. Sci., São Paulo, 39(6):296-300.

Silva R.A. \& Ferreira J.R. 2002b. Morfologia da artéria cerebelar superior do macaco prego (Cebus apella L., 1766): divisões e anastomose. Acta Scient.,
Health Sci. 24(3):687-695.<http://dx.doi.org/10.4025/actascihealthsci. v24i0.2486>

Silva R.A. \& Ferreira J.R. 2003. Estudos anatômicos das artérias cerebelares inferiores rostrais do macaco prego (Cebus apella Linnaeus, 1766. Primata - Cebidae). Publicações Avulsas do Instituto Pau Brasil de História Natural $7(1): 15-23$

Silva R.A., Ferreira J.R. \& Prada I.L.S. 2003. Estudo anatômico das artérias cerebelares inferiores caudais do macaco prego (Cebus Apella L., 1766). Arq. Ciênc. Saúde UNIPAR 7(2):107-112. <http://dx.doi.org/10.25110/ arqsaude.v7i2.2003.1064>

Siqueira Neto E.G.B. \& Ferreira J.R. 2002. Estudo anatômico da origem e distribuição dos ramos corticais das artérias cerebrais caudais do encéfalo do macaco prego (Cebus apella L., 1766). Acta Scient., Biol. Sci. 24(2):639646. <http://dx.doi.org/10.4025/actascibiolsci.v24i0.2369>

Sperino G.1897. Anatomia do Chimpanzé. Unione Tipográfico-Editrice, Torino, p.264-267.

Testut L. \& Latarjet A. 1954. Tratado de Anatomia Humana. Vol.2. SAT Editora, Rio de Janeiro, p.1239-1244.

Tilney F. 1928. The brain from ape to man: a contribution to the study of the evolution and development of the human brain. Paul B. Hoeber Inc., New York. 473p.

Watts J.W. 1934a. Ligation of the anterior cerebral artery in the monkey. J. Nervous Mental Dis. 79(2):153-158.

Watts J.W.1934b. A comparative study of the anterior cerebral artery and the circle of Willis in primates. J. Anat. 68(Pt 4):534-550. <PMid:17104503>

Weinstein J.D. \& Hedges Jr. T.R. 1962. Studies of intracranial and orbital vasculature of the rhesus monkey (Macaca mulatta). Anat. Rec. 144:37-41. <http://dx.doi.org/10.1002/ar.1091440106> <PMid:13999648> 